\title{
Novel Aeromonas hydrophila PPD134/91 Genes Involved in O-Antigen and Capsule Biosynthesis
}

\author{
Y. L. Zhang, ${ }^{1}$ E. Arakawa, ${ }^{2}$ and K. Y. Leung ${ }^{1,3 *}$ \\ Department of Biological Sciences, Faculty of Science, ${ }^{1}$ and Tropical Marine Science Institute, ${ }^{3}$ The National University of \\ Singapore, Singapore 117543, and Department of Bacteriology, National Institute of Infectious Diseases, Tokyo, Japan 162-8640 2
}

Received 10 July 2001/Returned for modification 14 September 2001/Accepted 3 January 2002

\begin{abstract}
The sequences of the $\mathrm{O}$-antigen and capsule gene clusters of the virulent Aeromonas hydrophila strain PPD134/91 were determined. The $O$-antigen gene cluster is 17,296 bp long and comprises 17 genes. Seven pathway genes for the synthesis of rhamnose and mannose, six transferase genes, one $O$ unit flippase gene, and one $\mathrm{O}$-antigen chain length determinant gene were identified by amino acid sequence similarity. PCR and Southern blot analysis were performed to survey the distribution of these 17 genes among 11 A. hydrophila strains of different serotypes. A. hydrophila PPD134/91 might belong to serotype 0:18, as represented by JCM3980; it contained all the same O-antigen genes as JCM3980 (97 to 100\% similarity at the DNA and amino acid levels). The capsule gene cluster of $A$. hydrophila PPD134/91 is 17,562 bp long and includes 13 genes, which were assembled into three distinct regions similar to those of the group II capsule gene cluster of Escherichia coli and other bacteria. Regions I and III contained four and two capsule transport genes, respectively. Region II had five genes which were highly similar to capsule synthesis pathway genes found in other bacteria. Both the purified $\mathrm{O}$-antigen and capsular polysaccharides increased the ability of the avirulent $A$. hydrophila strain PPD35/85 to survive in naïve tilapia serum. However, the purified surface polysaccharides had no inhibitory effect on the adhesion of $A$. hydrophila PPD134/91 to carp epithelial cells.
\end{abstract}

Surface polysaccharides, such as O-antigen and capsule, are important bacterial cell surface components. The O-antigen polysaccharide is covalently ligated to the lipid A-core complex and extends outward from the cell surface. The capsule is an extracellular polysaccharide enclosing the bacterium while remaining attached to the cell. Both the O-antigen polysaccharide and the capsule are composed of repeating oligosaccharide units (44). They act as prominent antigens and play important roles in the pathogenicity of many bacterial pathogens, such as protecting bacterial cells from complement-mediated serum killing $(20,30)$, acting as adhesion factors (31), protecting the bacteria from the effects of desiccation (38), and aiding survival in phagocytes (56). The serogrouping of bacterial strains within a genus is determined by the structural variability of surface polysaccharides. For example, Escherichia coli strains are divided into more than 160 serogroups based on the different surface polysaccharides (67). Klebsiella species have been classified into 72 serogroups based on the structural variability of their capsular polysaccharides (39).

Aeromonas hydrophila is an important pathogen of a wide variety of aquatic and terrestrial animals, especially fish (4). In fish, it causes hemorrhagic septicemia, which often results in high mortalities in commercial aquaculture. Some strains of $A$. hydrophila are also reported to cause infections in humans. The clinical symptoms include septicemia (17), meningitis (25), peritonitis (35), pneumonia (32), myonecrosis (34), and diarrhea (21). The genus Aeromonas has been classified into 96 serogroups $(50,60)$, and a role for surface polysaccharides in the pathogenicity of certain $A$. hydrophila strains has been

\footnotetext{
* Corresponding author. Mailing address: Department of Biological Sciences, Faculty of Science, The National University of Singapore, Science Dr. 4, Singapore, 117543. Phone: (65) 68747835. Fax: (65) 67792486. E-mail: dbslky@nus.edu.sg.
}

proposed. For example, the O-antigen lipopolysaccharide (LPS) of $A$. hydrophila O:34 strains has been found to play an important role in adhesion to HEp-2 cells (31). The O-polysaccharide from one virulent strain of $A$. hydrophila has been found to contain L-rhamnose and D-glucosamine and to have a backbone structure identical to that of the O-polysaccharide from Aeromonas salmonicida (53). The capsular polysaccharide has been found to be present in some serogroups of $A$. hydrophila, such as serotypes O:11 and O:34 (29). Two capsule genes from an O:34 strain (orf1 and wcaJ) have been found to confer serum resistance on E. coli K-12 strains (1). However, the genetics and genomic organization of surface polysaccharides of $A$. hydrophila have not been studied.

Bacterial genome subtraction was performed in our laboratory to examine the genetic differences between virulent (PPD134/91) and avirulent (PPD35/85) strains of $A$. hydrophila (71). Using four of the PPD134/91-specific genes, we employed long-range and genome-walking PCR to clone the O-antigen and capsule gene clusters from A. hydrophila PPD134/91. These two clusters were further characterized by computational analysis, and the distribution of $\mathrm{O}$-antigen genes among different serogroups of $A$. hydrophila was surveyed. The effects of purified O-antigen and capsule on serum resistance and adhesion to carp epithelial cells were also examined.

\section{MATERIALS AND METHODS}

Bacterial strains and plasmids. The bacterial strains and plasmids used in this study are listed in Table 1. A. hydrophila strains were maintained on tryptic soy agar (TSA) or in tryptic soy broth (TSB) (both from Difco, Detroit, Mich.) at $25^{\circ} \mathrm{C}$. E. coli strains were maintained on L agar or in Luria broth (LB) (both from $\mathrm{Difco})$ at $37^{\circ} \mathrm{C}$. When required, media were supplemented with ampicillin at 50 $\mu \mathrm{g} / \mathrm{ml}$. Bacteria were stored as frozen cultures at $80^{\circ} \mathrm{C}$ in either TSB or LB containing $25 \%$ (vol/vol) glycerol.

DNA manipulations and Southern hybridization. Bacterial genomic DNA was extracted according to the manuals for the genomic DNA isolation and purifi- 
TABLE 1. Bacterial strains and vectors used in this study

\begin{tabular}{|c|c|c|}
\hline $\begin{array}{l}\text { Strain or } \\
\text { plasmid }\end{array}$ & $\begin{array}{l}\text { Genotype and/or } \\
\text { relevant property }\end{array}$ & $\begin{array}{l}\text { Source }^{b} \text { or } \\
\text { reference }\end{array}$ \\
\hline \multicolumn{3}{|l|}{ Strains } \\
\hline \multicolumn{3}{|l|}{ A. hydrophila } \\
\hline ATCC 7966 & $\mathrm{O}: 1 ;$ virulent; type strain & ATCC \\
\hline JCM3968 & $0: 6$ & $\mathrm{JCM}$ \\
\hline JCM3973 & O:11 & $\mathrm{JCM}$ \\
\hline JCM3976 & O:14 & $\mathrm{JCM}$ \\
\hline JCM3978 & O:16 & $\mathrm{JCM}$ \\
\hline JCM3980 & O:18 & JCM \\
\hline JCM3981 & O:19 & JCM \\
\hline JCM3983 & $\mathrm{O}: 21$ & JCM \\
\hline JCM3984 & $\mathrm{O}: 22$ & $\mathrm{JCM}$ \\
\hline JCM3985 & $\mathrm{O}: 23$ & $\mathrm{JCM}$ \\
\hline JCM3996 & $\mathrm{O}: 34$ & JCM \\
\hline L15 & Avirulent & BAU \\
\hline L31 & Virulent & BAU \\
\hline L36 & Avirulent & BAU \\
\hline PPD35/85 & Avirulent & AVA \\
\hline PPD11/90 & Virulent & AVA \\
\hline PPD64/90 & Avirulent & AVA \\
\hline PPD88/90 & Avirulent & AVA \\
\hline PPD45/91 & Avirulent & AVA \\
\hline PPD70/91 & Virulent & AVA \\
\hline PPD122/91 & Virulent & AVA \\
\hline PPD134/91 & Virulent & AVA \\
\hline TF7 & O:11; virulent & UG \\
\hline E. coli strain $\mathrm{DH} 5 \alpha$ & Cloning host & \\
\hline \multicolumn{3}{|l|}{ Plasmids } \\
\hline pGEM-T Easy vector & Cloning vector; $A p^{r}$ & Promega \\
\hline pSC33 & $\begin{array}{l}\text { Subtracted fragment } 33 \text { cloned into } \\
\text { the RsaI site of the pT-Adv vector }\end{array}$ & 71 \\
\hline pSC46 & $\begin{array}{l}\text { Subtracted fragment } 46 \text { cloned into } \\
\text { the RsaI site of the pT-Adv vector }\end{array}$ & 71 \\
\hline pSC79 & $\begin{array}{l}\text { Subtracted fragment } 79 \text { cloned into } \\
\text { the RsaI site of the pT-Adv vector }\end{array}$ & 71 \\
\hline pSC86 & $\begin{array}{l}\text { Subtracted fragment } 86 \text { cloned into } \\
\text { the RsaI site of the pT-Adv vector }\end{array}$ & 71 \\
\hline
\end{tabular}

\footnotetext{
${ }^{a}$ Virulent strains were defined as having a lower $50 \%$ lethal dose in blue gourami or rainbow trout $\left(<10^{6.5}\right)$ than avirulent strains $\left(>10^{7.5}\right)$.

${ }^{b}$ ATCC, American Type Culture Collection; JCM, Japan Collection of Microorganisms; BAU, Bogor Agricultural University of Indonesia; AVA, AgriFood and Veterinary Authority, Singapore; UG, University of Guelph, Guelph, Ontario, Canada.
}

cation kits (Qiagen, Hilden, Germany; Bio 101, La Jolla, Calif.). Plasmid DNA was extracted by using a QIAprep spin miniprep kit, and restriction endonuclease digestion was accomplished by standard methods (51). Southern blotting was performed with the BluGene Non-Radioactive Nucleic Acid Detection System (Gibco-BRL, Gaithersburg, Md.) to characterize the conservation of the Oantigen genes of $A$. hydrophila PPD134/91 across other $A$. hydrophila strains. Transfer of DNA to nylon membranes (GeneScreen; NEN Research Products, Boston, Mass.), hybridization conditions, and visualization with streptavidinalkaline phosphate conjugates were carried out as recommended by the manufacturer's protocol.

DNA sequencing and sequence analysis. DNA sequencing was carried out on a PRISM 377 automated DNA sequencer by the dye termination method (Perkin-Elmer Applied Biosystems, Foster City, Calif.). The sequences were edited with the manufacturer's software. Sequence assembly and further editing were carried out with DNASIS DNA analysis software (Hitachi Software, San Bruno, Calif.). BLASTN, BLASTP, and BLASTX sequence homology analyses and a protein conserved-domain analysis (CD search) were performed by using the BLAST network server of the National Center for Biotechnology Information. Transmembrane helices in proteins were predicted by analyses at http://www.cbs .dtu.dk/services/TMHMM.

Long-range PCR and genome walking. Long-range PCR was performed using Taqplus long polymerase (Stratagene, La Jolla, Calif.). PCRs were carried out under the following conditions: one hold at $94^{\circ} \mathrm{C}$ for $1 \mathrm{~min}$, followed by 32 cycles of $94^{\circ} \mathrm{C}$ for $30 \mathrm{~s}, 56^{\circ} \mathrm{C}$ for $30 \mathrm{~s}$, and $72^{\circ} \mathrm{C}$ for 10 to $20 \mathrm{~min}$. GenomeWalker libraries were constructed by using five restriction enzymes (DraI, EcoRV, PvuII, ScaI, and StuI). PCR was performed by using Advantage Genomic Polymerase Mix (Clontech, Palo Alto, Calif.) and by following a two-step cycle protocol: 7 cycles of $2 \mathrm{~s}$ at $94^{\circ} \mathrm{C}$ and $4 \mathrm{~min}$ at $72^{\circ} \mathrm{C} ; 32$ cycles of $2 \mathrm{~s}$ at $94^{\circ} \mathrm{C}$ and $4 \mathrm{~min}$ at $67^{\circ} \mathrm{C}$. Amplified fragments were cloned into the pGEM-T Easy Vector (Promega, Madison, Wis.). The recombinant DNA molecules were transformed into E. coli DH5 $\alpha$ competent cells and sequenced.

Serotyping. The O:18 and O:34 antibodies were prepared, and agglutination tests for serotyping were performed, according to the protocols described previously by Sakazaki and Shimada (50). A. hydrophila strains JCM3980 (O:18) and JCM3996 (O:34) were used to raise antibodies for serotyping.

Examination of the bacterial capsule by electron microscopy. A drop of bacterial culture was placed on a coated grid for $1 \mathrm{~min}$ and blotted with filter paper. The glutaraldehyde-ruthenium red-uranyl acetate method was used to stain the cells (36). The sample was dried and observed by transmission electron microscopy.

Preparation of polysaccharides. The O-antigen polysaccharide was isolated and purified by the hot phenol-water extraction procedure (65). The capsular polysaccharide was isolated and purified by the method described by Martinez and coworkers (29).

Serum resistance assay. Naiive tilapia serum was used to perform the serum resistance assay. Bacteria were prepared and treated with $50 \%$ tilapia serum as described previously (64). Different concentrations (0.1 to $0.6 \mu \mathrm{g} / \mathrm{ml}$ ) of $A$. hydrophila PPD134/91 O-antigen and capsular polysaccharides were added to the serum in different tubes, followed by addition of washed $A$. hydrophila PPD35/85 (serum-sensitive strain) cells. The survival of $A$. hydrophila PPD35/85 was calculated by dividing the number of viable bacteria after a 1-h serum treatment by the number of bacteria before treatment. Bacteria with survival values greater than 1 were considered serum resistant, while those with values below 1 were considered serum sensitive. The data were obtained from three independent experiments.

Adhesion assay. Adhesion assays were performed as described previously with minor modifications (64). Briefly, 72-h-old epithelioma papillosum of carp (Cyprinus carpio) (EPC) cells in 24-well tissue culture plates were washed with Hanks' balanced salt solution (HBSS) and then incubated for an additional $30 \mathrm{~min}$ in tissue culture medium containing different concentrations $(0.1$ to $0.6 \mu \mathrm{g} / \mathrm{ml})$ of $\mathrm{O}$-antigen and capsular polysaccharides. Bacterial cells were then added and incubated for a further $30 \mathrm{~min}$. To measure the number of bacteria adhering to the monolayers, EPC cells were washed six times with HBSS and then lysed with $1 \%$ (vol/vol) Triton X-100 in phosphate-buffered saline, and bacterial numbers were determined by plate counting. Adhesion rates were calculated from the means of at least two wells in triplicate experiments. Final values were expressed as percentages relative to the value for the untreated control (absence of polysaccharides), which was set at $100 \%(n=3)$.

Statistical analysis. All data were expressed as means \pm standard errors of the means (SEM). Data were analyzed by one-way analysis of variance and a Duncan multiple-range test (SAS software; SAS Institute). $P$ values of $<0.05$ were considered significant.

Nucleotide sequence accession numbers. The DNA sequences of the $A$. hy drophila PPD134/91 O-antigen and capsule clusters and of the JCM3980 (O:18) $\mathrm{O}$-antigen cluster have been deposited in GenBank under accession no. AF146602, AF375657, and AF343089, respectively.

\section{RESULTS AND DISCUSSION}

Cloning and sequence analysis of the PPD134/91 O-antigen gene cluster. Suppression subtractive hybridization was used previously to identify genetic differences between $A$. hydrophila PPD134/91 (virulent strain) and PPD35/85 (avirulent strain) (71). Three PPD134/91-specific DNA fragments (F33, F46, and F86) were characterized as encoding $\mathrm{O}$-antigen biosynthesis genes, namely, rhamnosyltransferase (F46), mannosyltransferase B (F33), and phosphomannomutase (F86). The nucleotide sequence spanning the regions between F33 and F46 was 1,576 bp, and that between F33 and F86 was 3,556 bp (Fig. 1). Genome-walking PCR was performed upstream and downstream of the F46-to-F86 region, and the whole O-antigen cluster was determined to be 17,296 bp long (positions 2157 to 19452 in accession no. AF146602). Furthermore, a 2,156-bp 


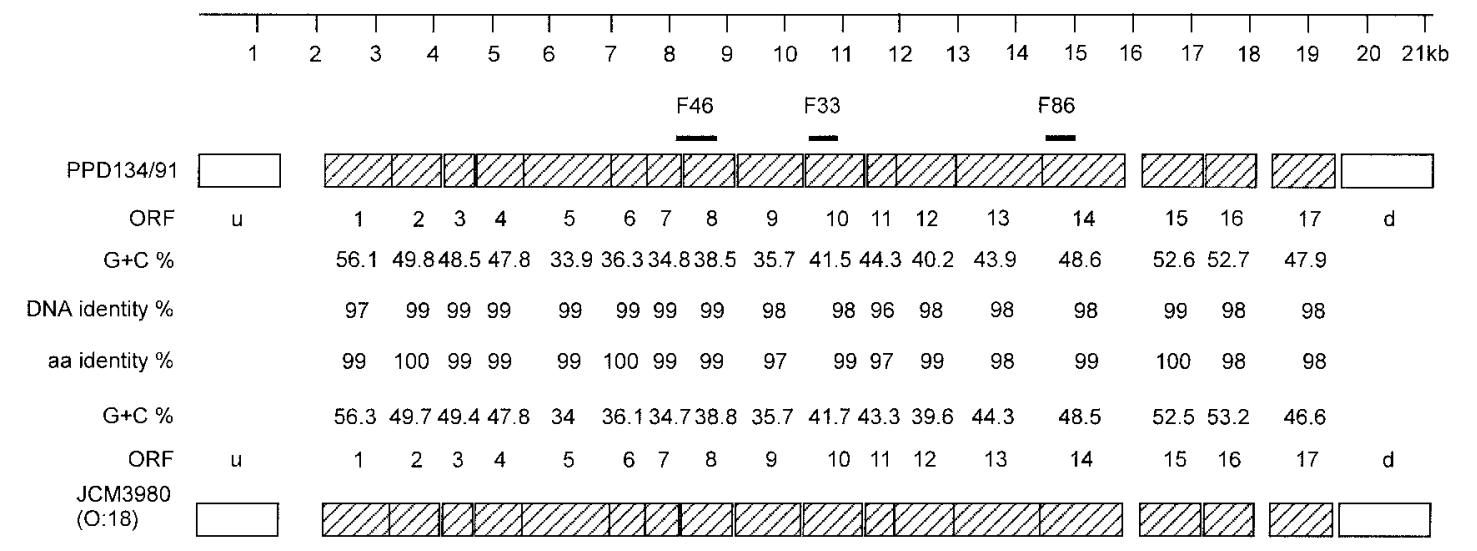

\begin{tabular}{|c|c|c|c|c|c|c|c|c|c|c|c|c|c|c|c|c|c|c|c|c|}
\hline 1 & 2 & 3 & 4 & 5 & 6 & 7 & 8 & 9 & 10 & 11 & 12 & 13 & 14 & 15 & 16 & 17 & 18 & 19 & 20 & $21 \mathrm{~kb}$ \\
\hline 1 & $\perp$ & 1 & 1 & 1 & 1 & $\perp$ & 1 & 1 & 1 & $\perp$ & $\downarrow$ & 1 & 1 & 1 & 1 & $\perp$ & 1 & 1 & 1 & $\perp$ \\
\hline
\end{tabular}

FIG. 1. Comparison of the $A$. hydrophila PPD134/91 O-antigen gene cluster with that of the $A$. hydrophila O:18 strain JCM3980. The three bars above the PPD134/91 O-antigen gene cluster map indicate the locations of the three subtracted fragments (F33, F46, and F86) which have been identified previously by suppression subtractive hybridization (71). The transcriptional directions for the O-antigen gene cluster and flanking sequences are from left to right.

sequence upstream of this cluster (positions 1 to 2156 in accession no. AF146602) and a 1,827-bp sequence downstream of this cluster (positions 19453 to 21279 in accession no. AF146602) were determined. Computer analysis demonstrated the presence of 17 putative open reading frames (ORFs) transcribed in the same direction in this O-antigen cluster. ORFs 1 and 2, ORFs 4 and 5, ORFs 5 and 6, ORFs 6 and 7, ORFs 11 and 12, ORFs 12 and 13, and ORFs 13 and 14 overlapped one another. ORF14 was separated from ORF15 by 304 bp, and ORF16 was separated by 270 bp from ORF17. The other ORFs were located one behind the other with a short distance, ranging from 1 to $26 \mathrm{bp}$, between them. This cluster was flanked by oprM upstream $\left(\mathrm{ORF}_{\mathrm{u}}\right)$ and one gene homologous to a hypothetical protein of Vibrio cholerae downstream $\left(\mathrm{ORF}_{\mathrm{d}}\right)$ (Fig. 1). A JUMPstart-like sequence, a 39-bp element located in the noncoding region upstream of many bacterial surface polysaccharide gene clusters (16), was found $64 \mathrm{bp}$ upstream of ORF1 of the cluster (positions 2054 to 2092 in accession no. AF146602). It may play a role in the regulation of O-antigen expression in PPD134/91, as JUMPstart sequences do in other bacteria (63). A possible transcriptional terminator with a hairpin loop structure (positions 19474 to 19491 in accession no. AF146602) was also found just downstream of ORF17. The nucleotide and amino acid sequences of the putative ORFs were used to search available databases for indications of possible functions; the results are summarized in Table 2 .

Distribution of O-antigen genes of PPD134/91 among various serotypes. Internal primers were designed for the $17 \mathrm{O}$ antigen ORFs. PCR was performed using the genomic DNAs from $23 \mathrm{~A}$. hydrophila strains of different O-serotypes as templates in order to survey their distribution among these strains. Those samples which had only one band at the same position in agarose gels as the coding gene in PPD134/91 were considered positive. At the same time, Southern blot analysis was performed to characterize the conservation of the $17 \mathrm{O}$-antigen genes of $A$. hydrophila PPD134/91 across the $23 A$. hydrophila strains. The results are summarized in Table 3. In general, results from the PCR analysis agreed with those of the Southern blot studies and were found to be more stringent and reliable. We found that different $\mathrm{O}$-serotypes of $A$. hydrophila strains shared some common features in their O-antigen gene clusters. ORF1s of PPD134/91 O-antigen genes were found to be present in at least 16 other $A$. hydrophila O-serotypes. JCM3980 (O:18) was found to contain all the same O-antigen genes as PPD134/91 (Table 3). At least 13 ORFs were found to be present in JCM3996 (O:34), and at least 12 ORFs were present in PPD64/90.

We also serotyped $A$. hydrophila PPD134/91, JCM3980 (O:18), and JCM3996 (O:34) using antisera raised against JCM3980and JCM3996. Both anti-JCM3980 (O:18) and JCM3996 (O:34) antibodies strongly reacted with $A$. hydrophila PPD134/91, JCM3980, and JCM3996 (data not shown). Our serotyping studies revealed that serogroups O:18 and O:34 are closely related and that $A$. hydrophila PPD134/91 might belong to one of these two serogroups. This result was confirmed by Sakazaki and Shimada (50), who reported that O:18 antiserum cross-reacted with O:34 antigen. The O-antigens of serogroups $\mathrm{O}: 18$ and O:34 might have some common characteristics in sugar components and structure. Our results also suggested that $A$. hydrophila PPD134/91 could belong to serogroup O:18 based on serotyping and PCR results. Long-range PCR was therefore performed to clone the $\mathrm{O}$-antigen cluster from strain JCM3980 (O:18), and its DNA sequences were determined. The whole O-antigen cluster for JCM3980 was determined to be 17,297 bp long (positions 2155 to 19451 in accession no. AF343089). DNA and putative amino acid sequence analyses showed that the O-antigen clusters from strains JCM3980 (O: 18) and PPD134/91 shared 97 to $100 \%$ identity at both the DNA and amino acid levels (Fig. 1). These two strains had the same $\mathrm{O}$-antigen genes and the same gene organization in their $\mathrm{O}$-antigen gene clusters. Based on this information, we propose that PPD134/91 belongs to serotype O:18.

Genetic organization of the $\mathbf{O}$-antigen and capsule clusters. Genes involved in the biosynthesis of surface polysaccharides are generally arranged in clusters. E. coli has several such 
TABLE 2. Properties of ORFs in the region responsible for O-antigen polysaccharide synthesis and flanking regions

\begin{tabular}{|c|c|c|c|c|c|c|c|c|}
\hline $\begin{array}{c}\text { Potential } \\
\text { ORF }\end{array}$ & $\begin{array}{l}\text { No. of } \\
\text { amino } \\
\text { acids }\end{array}$ & $\begin{array}{c}\text { Nucleotide } \\
\text { position in } \\
\text { sequence }\end{array}$ & Predicted function & $\begin{array}{l}\text { Homolo- } \\
\text { gous gene }\end{array}$ & Bacterium & $\begin{array}{c}\% \text { Identity } \\
\text { (no. of amino } \\
\text { acids) }\end{array}$ & $\begin{array}{c}\text { Accession } \\
\text { no. }\end{array}$ & Reference \\
\hline $\mathrm{ORF}_{\mathrm{u}}$ & 475 & $1-428$ & $\begin{array}{l}\text { Outer membrane protein OprM } \\
\text { precursor }\end{array}$ & oprM & Pseudomonas aeruginosa & $63(467)$ & Q51487 & 43 \\
\hline ORF1 & 379 & 2157-3296 & dTDP-D-glucose-4,6-dehydratase & $\mathrm{rm} / \mathrm{B}$ & S. enterica & $77(361)$ & AF279619.1 & 24 \\
\hline ORF2 & 287 & $3296-4159$ & $\begin{array}{l}\text { Glucose-1-phosphate thymidylyl } \\
\text { transferase }\end{array}$ & $\mathrm{rm} / \mathrm{A}$ & E. coli & $75(287)$ & $\mathrm{P} 27831$ & 27 \\
\hline ORF3 & 183 & $4171-4722$ & $\begin{array}{l}\text { dTDP-4-dehydrorhamnose } 3,5- \\
\text { epimerase }\end{array}$ & $\mathrm{rm} / \mathrm{C}$ & Serratia marcescens & $61(167)$ & T31086 & 49 \\
\hline ORF4 & 275 & $4725-5552$ & dTDP-glucose-4,6-dehydratase & $s p s \mathrm{~J} / r m l B$ & Bacillus subtilis & $34(137)$ & S39727 & 14 \\
\hline ORF5 & 488 & $5552-7018$ & O-unit flippase & $w z x$ & E. coli & $20(407)$ & AAC44886.1 & 63 \\
\hline ORF6 & 211 & $6990-7625$ & O-acetyltransferase & cap $5 \mathrm{H}$ & Staphylococcus aureus & $38(184)$ & $\mathrm{AAC} 46100$ & 5 \\
\hline ORF7 & 196 & $7622-8212$ & Acetyltransferase & $w c f D$ & Bacteroides fragilis & $28(192)$ & AAD40715 & 10 \\
\hline ORF8 & 295 & $8216-9103$ & Rhamnosyltransferase & cps $19 \mathrm{bQ}$ & Streptococus pneumoniae & $46(145)$ & AAB 66522 & 33 \\
\hline ORF9 & 405 & $9105-10322$ & Integral membrane protein & & Campylobacter jejuni & $30(181)$ & A81263 & 40 \\
\hline ORF10 & 345 & $10349-11386$ & Mannosyltransferase-like protein & $w b y K$ & Y. pseudotuberculosis & $57(309)$ & CAB63299 & 54 \\
\hline ORF11 & 199 & 11390-11989 & O-acetyltransferase & $w b b J$ & E. coli & $46(169)$ & P37750 & 69 \\
\hline ORF12 & 332 & $11979-12977$ & EpsL & eps $L$ & Lactobacillus delbrueckii & $59(273)$ & AF267127 & Direct submission $^{a}$ \\
\hline ORF13 & 501 & $12922-14427$ & $\begin{array}{l}\text { Mannose-1-phosphate guanylyl- } \\
\text { transferase }\end{array}$ & $\operatorname{man} C$ & E. coli & $61(428)$ & H64970 & 3 \\
\hline ORF14 & 476 & $14424-15854$ & Phosphomannomutase & $\operatorname{man} B$ & S. enterica serovar Typhi & $59(475)$ & P26405 & 72 \\
\hline ORF15 & 341 & $16159-17184$ & $\begin{array}{l}\text { Colanic biosynthesis UDP-glucose } \\
\text { lipid carrier transferase }\end{array}$ & $w c a J$ & E. coli & $44(173)$ & P71241 & 58 \\
\hline ORF16 & 300 & $17191-18093$ & $\begin{array}{l}\text { dTDP-6-deoxy-L-mannose- } \\
\text { dehydrogenase }\end{array}$ & $r m l D$ & S. enterica & $46(252)$ & AAG09499 & 24 \\
\hline ORF17 & 362 & 18364-19452 & O-antigen chain length determinant & $c l d / w z z$ & Y. pseudotuberculosis & $24(350)$ & AAC44859 & 57 \\
\hline $\mathrm{ORF}_{\mathrm{d}}$ & 571 & 19564-21279 & Sodium/proline symporter Vca1071 & & V. cholerae & $40(376)$ & H82382 & 15 \\
\hline
\end{tabular}

${ }^{a}$ Direct submission to GenBank.

clusters, including $r f a$ (LPS core), $r f b$ (O-antigen), cps (group I capsules and colanic acid), and kps (group II K capsules) (46). These gene clusters have three classes of genes: those required for the enzymes involved in the biosynthesis pathways of nucleotide sugars, genes for the glycosyltransferases, and genes for oligosaccharide or polysaccharide processing (44). We also observed these three gene classes in the $\mathrm{O}$-antigen and capsule clusters of $A$. hydrophila PPD134/91.

Pathway genes in the $\mathbf{O}$-antigen cluster. Two sugar synthesis pathways, for rhamnose and mannose, were identified in the

TABLE 3. Distribution of O-antigen ORFs of PPD134/91 among various $A$. hydrophila strains

\begin{tabular}{|c|c|c|c|c|c|c|c|c|c|c|c|c|c|c|c|c|c|c|}
\hline \multirow{2}{*}{ Strain } & \multirow{2}{*}{$\begin{array}{l}\text { Sero- } \\
\text { group }\end{array}$} & \multicolumn{17}{|c|}{ O-antigen ORF of $A$. hydrophila PPD134/91 ${ }^{a}$} \\
\hline & & 1 & 2 & 3 & 4 & 5 & 6 & 7 & 8 & 9 & 10 & 11 & 12 & 13 & 14 & 15 & 16 & 17 \\
\hline ATCC 7966 & $\mathrm{O}: 1$ & $(+)$ & - & $(+)$ & $(+)$ & $(+)$ & - & - & - & - & - & - & $(+)$ & $(+)$ & $(+)$ & $(+)$ & - & - \\
\hline JCM 3968 & O:6 & + & - & $(+)$ & $(+)$ & $(+)$ & - & - & - & - & - & + & $(+)$ & $(+)$ & $(+)$ & $(+)$ & - & - \\
\hline JCM3973 & O:11 & + & - & $(+)$ & $(+)$ & - & - & $(+)$ & - & - & - & $(+)$ & $(+)$ & - & $(+)$ & $(+)$ & - & + \\
\hline JCM3976 & O:14 & + & - & $(+)$ & $(+)$ & - & - & - & - & - & - & - & - & - & $(+)$ & $(+)$ & - & - \\
\hline JCM3978 & O:16 & + & + & $(+)$ & $(+)$ & $(+)$ & - & $(+)$ & - & - & $(+)$ & - & - & - & $(+)$ & $(+)$ & - & $(+)$ \\
\hline JCM3980 & O:18 & + & + & + & + & + & + & + & + & + & + & + & + & + & + & + & + & + \\
\hline JCM3981 & O:19 & $(+)$ & - & $(+)$ & $(+)$ & $(+)$ & - & $(+)$ & - & - & - & - & - & - & $(+)$ & $(+)$ & - & - \\
\hline JCM3983 & $\mathrm{O}: 21$ & + & - & $(+)$ & $(+)$ & $(+)$ & - & $(+)$ & - & - & - & - & - & - & $(+)$ & - & - & - \\
\hline JCM3984 & $\mathrm{O}: 22$ & + & - & $(+)$ & $(+)$ & $(+)$ & - & - & - & - & - & - & $(+)$ & $(+)$ & $(+)$ & $(+)$ & - & - \\
\hline JCM3985 & $\mathrm{O}: 23$ & - & - & $(+)$ & $(+)$ & $(+)$ & - & - & - & - & + & - & $(+)$ & $(+)$ & $(+)$ & - & - & $(+)$ \\
\hline JCM3996 & $\mathrm{O}: 34$ & + & + & + & + & + & $(+)$ & $(+)$ & $(+)$ & + & - & + & + & + & + & + & + & + \\
\hline L15 & Unknown & - & - & $(+)$ & $(+)$ & - & - & - & - & - & - & - & - & - & - & - & - & - \\
\hline L31 & Unknown & + & - & - & $(+)$ & - & - & - & - & - & - & - & - & - & - & - & - & - \\
\hline L36 & Unknown & - & - & $(+)$ & $(+)$ & - & - & - & - & - & - & - & - & - & - & - & - & - \\
\hline PPD35/85 & Unknown & - & - & $(+)$ & $(+)$ & - & - & $(+)$ & - & - & - & - & - & - & - & - & - & - \\
\hline PPD11/90 & Unknown & + & - & $(+)$ & $(+)$ & - & - & $(+)$ & - & - & - & - & $(+)$ & $(+)$ & $(+)$ & - & - & - \\
\hline PPD64/90 & Unknown & + & + & + & + & + & $(+)$ & $(+)$ & $(+)$ & $(+)$ & $(+)$ & + & + & + & + & + & + & + \\
\hline PPD88/90 & Unknown & + & - & $(+)$ & $(+)$ & $(+)$ & - & $(+)$ & - & - & $(+)$ & - & - & $(+)$ & $(+)$ & - & - & $(+)$ \\
\hline PPD45/91 & Unknown & + & - & - & - & - & - & - & - & - & - & - & - & - & - & - & - & - \\
\hline PPD70/91 & Unknown & + & - & $(+)$ & $(+)$ & - & - & $(+)$ & - & - & - & - & - & $(+)$ & $(+)$ & - & - & - \\
\hline PPD122/91 & Unknown & + & - & $(+)$ & $(+)$ & $(+)$ & - & $(+)$ & - & - & - & $(+)$ & - & - & $(+)$ & - & - & - \\
\hline PPD134/91 & O:18 & + & + & + & + & + & + & + & + & + & + & + & + & + & + & + & + & + \\
\hline TF7 & O:11 & $(+)$ & - & $(+)$ & $(+)$ & $(+)$ & - & $(+)$ & - & - & - & - & - & - & $(+)$ & $(+)$ & - & - \\
\hline
\end{tabular}

${ }^{a}$ Internal primers were designed for the 17 O-antigen ORFs. PCR was performed using genomic DNAs from different $A$. hydrophila strains as templates in order to survey their distribution among these strains. Those samples which had only one band of the same size as the coding gene in PPD134/91 were taken as positive. Southern hybridization was also employed to confirm the distributions of the 17 O-antigen ORFs among these strains. Symbols: + , positive; - , negative; $(+)$, strains which were negative in PCR results but positive in Southern hybridization analysis. 

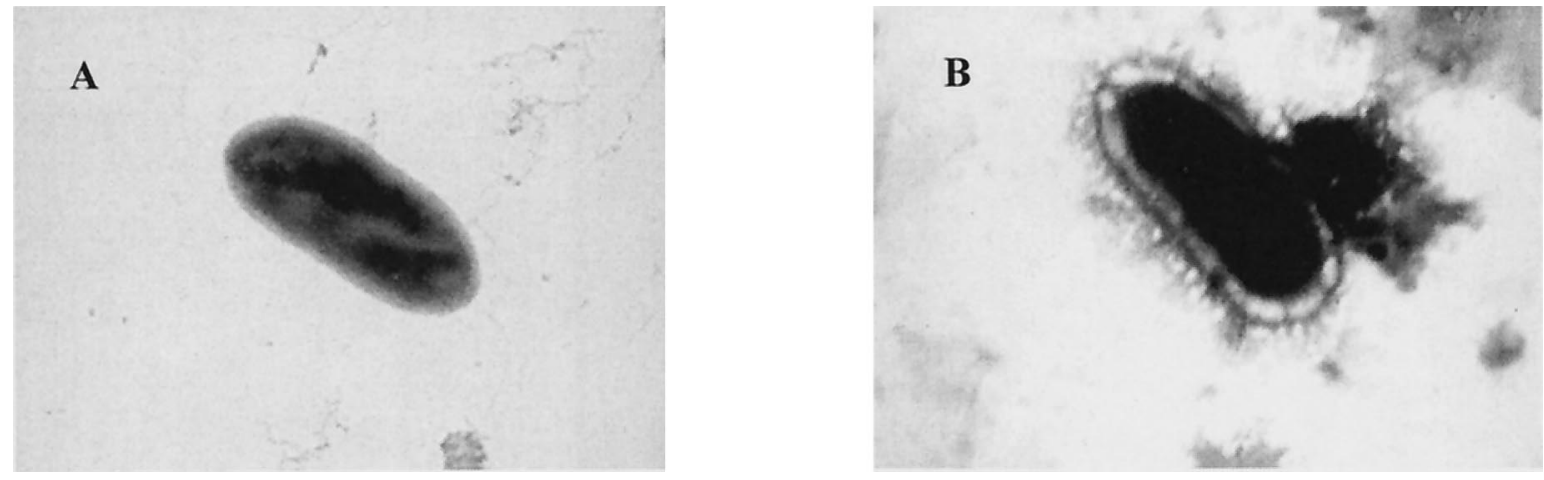

FIG. 2. Transmission electron micrographs of negatively stained cells of $A$. hydrophila PPD35/85 (A) and PPD134/91 (B).

O-antigen cluster of $A$. hydrophila PPD134/91. ORFs 1, 2, 3, 4, and 16 of the O-antigen cluster were homologous to $r m l B$, $r m l A, r m l C, r m l B$, and $r m l D$ of other bacteria, respectively (Table 2). The products of $r m l A$ through $r m l D$ are responsible for the biosynthesis of dTDP-L-rhamnose from glucose-1-phosphate (24). Rhamnose is a component of surface polysaccharide and is present in many bacterial polysaccharides. The four rhamnose synthesis pathway genes are usually found as a block in surface polysaccharide gene clusters, and they are highly conserved throughout all species $(24,52)$. However, the $r m l D$ gene in the $A$. hydrophila PPD134/91 O-antigen cluster was separated from the other three genes ( $r m l A$ through $r m l C)$ of the rhamnose synthesis pathway. There are two ORFs (ORFs 1 and 4) in this cluster which are homologous to $r m l B$, and they may perform the same function in O-antigen synthesis. Alternatively, it is also possible that ORFs 1 and 4 may function differently in the synthesis of different sugars, since $r m l B$ is also involved in the biosynthesis of two other sugars, dTDP- $N$ acetylfucosamine (22) and dTDP- $N$-acetylviosamine (44). However, confirmation of these speculations awaits the determination of the sugar component of the O-antigen and detailed functional analysis of these genes. It is also possible that the O-antigen of strain PPD134/91 contains mannose, because ORFs 13 and 14 encode mannose-1-phosphate guanylyltransferase and phosphomannomutase, respectively. These two proteins work together to synthesize GDP-mannose from mannose-6-phosphate (18).

Transferase genes in the $\mathbf{O}$-antigen cluster. ORFs 8 and 10 were identified as encoding rhamnosyltransferase and mannosyltransferase, respectively, by their sequence similarities (Table 2). They may function in the transfer of the synthesized nucleotide sugar monomers to the growing O-unit.

$\mathrm{O}$ acetylation of the $\mathrm{O}$-antigen sugar residues is one of the commonest forms of $\mathrm{O}$-polysaccharide modification. $\mathrm{O}$ acetylation of the O-polysaccharide leads to changes in antigenic properties and $\mathrm{O}$-specific phage resistance, thus increasing the polymorphism of the O-antigen $(44,52)$. ORFs 6,7 , and 11 were found to be homologous to O-acetyltransferases of other bacteria (Table 2). These three genes may play a role in the addition of acetyl groups to different sugar residues or to different positions of the nucleotide sugar. Determination of their distribution by PCR analysis showed that ORFs 6 and 7 were present only in PPD134/91 and the O:18 strain JCM3980 (Table 3). ORF11 was found to be present in PPD134/91, the O:6 strain JCM3968, the O:18 strain JCM3980, the O:34 strain
JCM3996, and PPD64/90 by PCR analysis. These results indicated that ORFs 6 and 7 might be O:18 specific. They may be involved in transferring acetyl groups to the positions which define the O:18 serogroup. ORF11 may transfer acetyl groups to the same position of the same sugars of these three $\mathrm{O}$ antigens.

The O-units are synthesized in the cytoplasm and are initiated by transfer of GalNAc or GlcNAc onto a lipid carrier, undecaprenol phosphate (66). ORF15 showed similarity to UDP-glucose lipid carrier transferase or UDP-galactose phosphate transferase for $\mathrm{O}$-antigens or capsules of various bacteria $(7,58)$. Results of a conserved-domain database search showed that ORF15 was homologous to UDP-galactose-lipid carrier transferase (7) and galactosyltransferase, which catalyzes the addition of galactose to an oligosaccharide precursor or a lipid intermediate $(47,70)$. Both UDP-galactose-lipid carrier transferase and UDP-glucose lipid carrier transferase were predicted to be integral membrane proteins (66). A search of transmembrane helices showed that the putative protein encoded by ORF15 was an integral membrane protein with three transmembrane domains. ORF15 might initiate the O-unit synthesis of PPD134/91 by transferring galactose or glucose to the lipid carrier. However, further experiments are needed to determine its function in O-antigen synthesis by PPD134/91.

Saccharide-processing genes in the $\mathbf{O}$-antigen cluster. It was noted that only a few gene products of surface polysaccharide genes have extensive potential transmembrane domains (52). In the $\mathrm{O}$-antigen gene clusters, the $\mathrm{O}$-antigen flippase (Wzx) and O-antigen polymerase (Wzy) were found to contain several transmembrane domains. These two genes are species specific, and transmembrane domains are important for their identification. Transmembrane region search results indicated that ORF5 had 12 transmembrane segments, while ORF9 contained 9 transmembrane domains. ORF5 is similar to the Ounit flippases of E. coli (62) and Salmonella enterica (23). We deduced that ORF5 might be O-unit flippase and ORF9 might perform the function of polymerization of the O-antigen polysaccharide in PPD134/91. ORF17 is similar to Cld/Wzz of Yersinia pseudotuberculosis. This gene might be involved in the regulation of $\mathrm{O}$-antigen chain length.

Group II capsule gene cluster in PPD134/91. When strains of $A$. hydrophila were negatively stained with ruthenium red, capsules were seen as electron-dense reticulated networks surrounding the PPD134/91 (Fig. 2B) and JCM3980 (O:18) (data not shown) cells. However, capsules were not observed for 
A

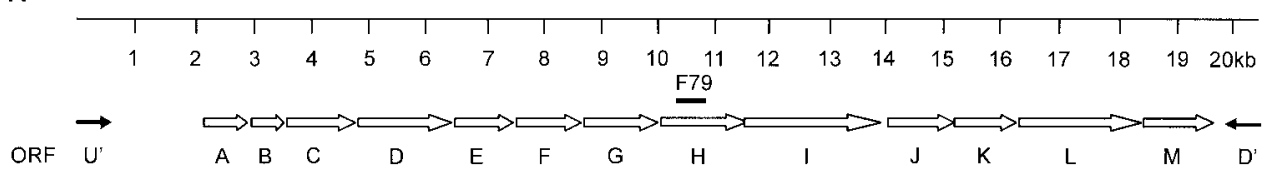

B

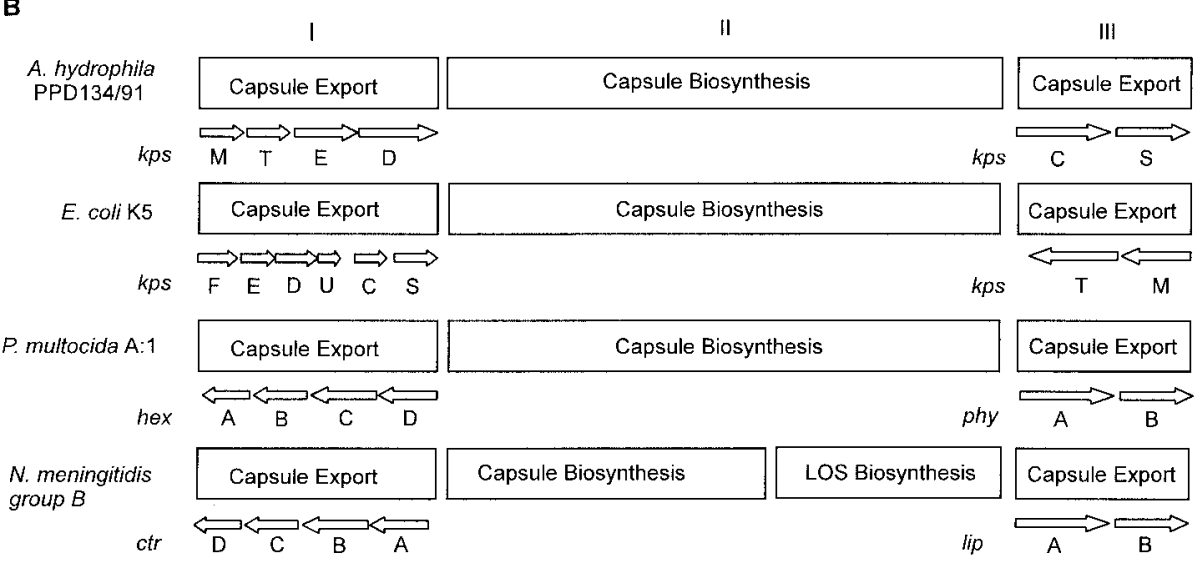

FIG. 3. Genetic organization of the A. hydrophila PPD134/91 capsule cluster and comparison with those of three other bacteria. (A) Organizational map of the $A$. hydrophila PPD134/91 capsule gene cluster. ORFs within the operon, with the direction of transcription, are indicated by open arrows. The corresponding gene designation is shown under each ORF. The location in this cluster of F79, which has been identified previously by suppression subtractive hybridization (71), is indicated by a bar above the map. Flanking genes and their transcriptional directions are shown as filled arrows. (B) Genetic organization of the capsule clusters of A. hydrophila PPD134/91, E. coli K5, P. multocida A:1, and N. meningitidis group B $(9,13,45)$. The organization of the locus into three regions is indicated by open boxes.

PPD35/85 cells (Fig. 2A). The nucleotide sequences of the PPD134/91 capsule cluster were determined by genome-walking PCR. The first pair of genome-walking primers anneal to the two ends of F79 (Fig. 3). Genome walking was done until the first flanking genes of the two ends of the cluster were found. F79, from our previous genome subtraction experiment (71), was studied due to its low $\mathrm{G}+\mathrm{C}$ content $(30.6 \%)$. The gene cluster for capsule synthesis of PPD134/91 can be divided into three regions, like many group II capsule gene clusters of other bacteria, such as E. coli (45), Pasteurella multocida $(6,8)$, and Neisseria meningitidis (13) (Fig. 3). All of the known capsule assembly systems seen in gram-negative bacteria are represented in E. coli. E. coli therefore has provided a variety of working models on which studies with other bacteria are based (67). In E. coli, the group II capsule cluster comprises three distinct regions. Regions I and II contain the genes kpsDEMT and $k p s C S$, respectively, and the proteins encoded are involved in the maturation and export of the capsular polysaccharide. Genes in region II are serotype specific and encode proteins for biosynthesis of the polysaccharide.

In $E$. coli, the capsular polysaccharide is synthesized on the cytoplasmic face of the plasma membrane and transported across the plasma membrane by an ABC-2 (ATP-binding cassette) transporter (67). The ABC-2 of the E. coli group II capsule consists of KpsM (the transmembrane component) and KpsT (the ATPase component). KpsM has an ATP-binding fold and contains at least six potential membrane-spanning domains $(41,55)$. It was speculated that the group II capsular polysaccharide transporter system comprises two molecules of $\mathrm{KpsM}$ to form some type of inner-membrane-spanning pore and two molecules of KpsT to catalyze ATP hydrolysis and energize the transport process. KpsE and KpsD were sug- gested to be components of the biosynthetic/export complex located on the plasma membrane to form a multiprotein "capsule assembly complex," thus mediating the translocation of the capsular polysaccharide to the cell surface (67). KpsE of $E$. coli encodes a protein which contains one transmembrane domain in its $\mathrm{N}$ terminus to anchor to the plasma membrane, one large periplasmic domain of 300 amino acids (aa), and one C-terminal transmembrane domain. $\mathrm{KpsC}$ and $\mathrm{KpsS}$ were speculated to play critical roles in production of the $E$. coli group II capsule and group-II-like capsules of other gramnegative bacteria such as Haemophilus influenzae and N. meningitidis (12). They might be involved in the attachment of 3-deoxy-D-manno-octulosonate (KDO) to phospholipids and the subsequent ligation of the capsular polysaccharide to phosphatidyl-KDO (46).

Sequence analysis of the PPD134/91 capsule gene cluster. The PPD134/91 capsule cluster is 17,562 bp and includes 13 ORFs transcribed in the same direction (positions 2148 to 19709 in accession no. AF375657). Furthermore, a 2,147-bp sequence upstream of this capsule cluster and a 752-bp sequence downstream were determined. The nucleotide and amino acid sequences were used to search GenBank for homologues so that their possible functions could be deduced. The capsule cluster was flanked by a gene (ORFU') homologous to an unknown $V$. cholerae gene $(v c 1870)$ upstream and a gene (ORFD') homologous to an arginine/ornithine transport system permease gene (aotM) downstream. A possible transcriptional terminator with a hairpin loop structure (positions 19733 to 19761 in accession no. AF375657) was also found downstream of ORFM. The whole cluster can be divided into three regions as described below (Fig. 3 and Table 4).

Region I consists of four ORFs. ORFs A through D dem- 
TABLE 4. Properties of ORFs in the region responsible for capsular polysaccharide synthesis and flanking regions

\begin{tabular}{|c|c|c|c|c|c|c|c|c|}
\hline $\begin{array}{l}\text { Potential } \\
\text { ORF }\end{array}$ & $\begin{array}{c}\text { No. of } \\
\text { amino } \\
\text { acids }\end{array}$ & $\begin{array}{l}\text { Nucleotide } \\
\text { position in } \\
\text { sequence }\end{array}$ & Predicted function & $\begin{array}{l}\text { Homolo- } \\
\text { gous gene }\end{array}$ & Bacterium & $\begin{array}{c}\% \text { Identity } \\
\text { (no. of amino } \\
\text { acids) }\end{array}$ & $\begin{array}{l}\text { Accession } \\
\text { no. }\end{array}$ & Reference \\
\hline ORFU' & 213 & $1-642$ & Unknown & $v c 1870$ & V. cholerae & $33(178)$ & D82145 & 15 \\
\hline ORFA & 241 & $2148-2873$ & Capsule transport protein & $k p s M$ & E. coli & $64(241)$ & AAD31428 & 9 \\
\hline ORFB & 163 & $3038-3529$ & Capsule transport protein & kps $T$ & E. coli & $82(163)$ & AAD31429 & 9 \\
\hline ORFC & 397 & $3562-4755$ & Capsule transport protein & kpsE & E. coli & $68(388)$ & AAC38080 & 48 \\
\hline ORFD & 546 & $4776-6416$ & Polysialic acid transport protein & $k p s D$ & E. coli & $50(222)$ & AAA21682 & 68 \\
\hline ORFE & 346 & $6424-7464$ & Unknown & $b c b I$ & P. multocida & $35(328)$ & AAF67271 & 6 \\
\hline ORFF & 391 & $7510-8685$ & $\begin{array}{l}\text { UDP- } N \text {-acetylglucosamine-2- } \\
\text { epimerase }\end{array}$ & ecs $4719 /$ wecB & E. coli $\mathrm{O} 157: \mathrm{H} 7$ & $63(368)$ & BAB38142 & 26 \\
\hline ORFG & 418 & $8754-10010$ & $\begin{array}{l}\text { UDP- } N \text {-acetyl-D-mannosamin- } \\
\text { uronic acid dehydrogenase }\end{array}$ & $e c b B$ & P. multocida & $69(344)$ & AAK17910 & 61 \\
\hline ORFH & 500 & $10056-11558$ & Unknown & $e c b I$ & P. multocida & $40(154)$ & AAK17917 & 61 \\
\hline ORFI & 819 & $11488-13947$ & Glycosyltransferase & $\operatorname{glg} A$ & S. coelicolor A3(2) & $31(63)$ & CAB50741 & 28 \\
\hline ORFJ & 397 & $14009-15202$ & Unknown & & Mannheimia haemolytica & $22(262)$ & AAF08245 & 73 \\
\hline ORFK & 360 & 15199-16281 & Capsule biosynthesis protein & $s a c D$ & N. meningitidis serogroup A & $25(288)$ & AAC38288 & 59 \\
\hline ORFL & 694 & $16304-18388$ & Capsule export protein & kpsC & E. coli & $77(510)$ & AAD32183 & 9 \\
\hline ORFM & 437 & 18396-19709 & Capsule export protein & $k p s S$ & E. coli & $39(342)$ & P42218 & 42 \\
\hline ORFD' $^{\prime}$ & 230 & 19769-20461 & $\begin{array}{l}\text { Arginine/ornithine transport } \\
\text { system permease protein }\end{array}$ & aotM & P. aeruginosa & $54(227)$ & T44456 & 37 \\
\hline
\end{tabular}

onstrated considerable similarity to the genes encoding E. coli capsule transport proteins KpsM, KpsT, KpsE, and KpsD, respectively (Table 4). ORFA was separated from ORFB by $164 \mathrm{bp}$, and ORFB was separated by $32 \mathrm{bp}$ from the following ORFC. ORFC was in turn separated from ORFD by $20 \mathrm{bp}$. Region III includes two ORFs, ORFs L and M, which are similar to KpsC and KpsS encoded by E. coli capsule genes, respectively. ORFL was separated by $22 \mathrm{bp}$ from ORFK. ORFM was separated by $7 \mathrm{bp}$ from ORFL. ORFA of the capsular polysaccharide cluster of PPD134/91 contains six transmembrane domains, and ORFB contains one ATP-binding domain. ORFC encodes a 397-aa protein including two transmembrane domains, aa 44 to 66 and aa 368 to 390, and a periplasmic domain, aa 67 to 367 . We can deduce that the products of ORFs A through D perform functions similar to those of E. coli KpsM, KpsT, KpsE, and KpsD, respectively. ORFs $\mathrm{L}$ and $\mathrm{M}$ may play roles in the synthesis of the PPD134/91 capsule similar to those of KpsC and KpsS in E. coli and other bacteria.

Region II of the PPD134/91 capsule gene cluster consists of seven ORFs (ORFs E through K). ORFs $\mathrm{H}$ and I and ORFs J and $\mathrm{K}$ overlap one another by 71 and $4 \mathrm{bp}$, respectively. The rest of the ORFs are separated from one another by $7 \mathrm{bp}$ (for ORFs D and E) to 68 bp (ORFs F and G). ORFs F and G showed high similarity over their entire lengths with genes encoding UDP- $N$-acetyl-D-glucosamine 2-epimerase and UDP$N$-acetyl-D-mannosaminuronic acid dehydrogenase of other bacteria, respectively. These two enzymes catalyze the synthesis of UDP-ManNAcA from UDP-GlcNAc. It is reasonable to deduce that the capsule of PPD134/91 contains UDPManNAcA. ORFE was homologous to the $P$. multocida capsule biosynthesis gene encoding BcbI, whose function is still unknown (6). The functions of ORFs E, H, and J cannot be proposed, since there are no homologous genes whose functions are known in the existing GenBank database. ORFI was similar to glycosyltransferase of Streptomyces coelicolor (28). ORFI either could be a transferase gene responsible for the transfer of the UDP-ManNAcA monomer to the growing polysaccharide unit or could be involved in another nucleotide sugar biosynthesis pathway together with other unknown genes present in this cluster.

Purification and functional study of the surface polysaccharides of PPD134/91. O-antigen and capsular polysaccharides were purified from $A$. hydrophila PPD134/91. A serum resistance assay and an adhesion assay were performed with and without the addition of different concentrations of polysaccharides $(0.1$ to $0.6 \mu \mathrm{g} / \mathrm{ml})$. A. hydrophila PPD134/91 was serum resistant, and the survival index was calculated as $2.22 \pm 0.18$ $(n=3)$ after a 1 -h treatment with tilapia serum, while PPD35/85 was serum sensitive (survival index, $0.019 \pm 0.002$ ). The survival ability of PPD35/85 in tilapia serum increased with increasing concentrations of $\mathrm{O}$-antigen and capsular polysaccharides, but at different levels (Fig. 4). With the addition of $0.6 \mu \mathrm{g}$ of purified O-antigen and capsular polysaccharides $/ \mathrm{ml}$,

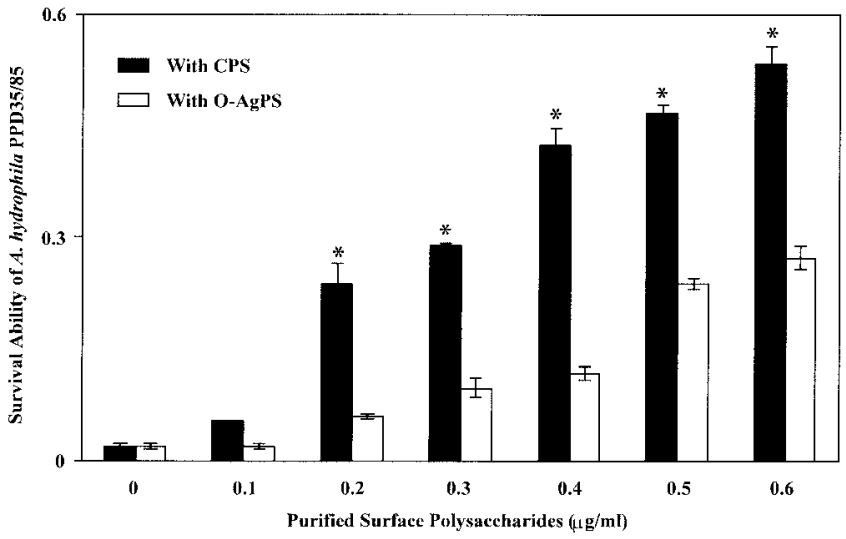

FIG. 4. Survival of $A$. hydrophila PPD35/85 in fresh naïve tilapia serum with different concentrations of purified surface polysaccharides of $A$. hydrophila PPD134/91. Survival of PPD35/85 in the serum without addition of surface polysaccharides was determined as a control. Results are expressed as means \pm SEM from three independent experiments. On a weight basis, the capsular polysaccharide (CPS) was significantly (asterisks) more effective than the $\mathrm{O}$-antigen polysaccharide (O-AgPS) in protecting $A$. hydrophila PPD35/85 against serummediated killing $(P<0.05)$. 
the survival index of $A$. hydrophila PPD35/85 increased to 0.27 \pm 0.02 (14.2-fold) and $0.53 \pm 0.02$ (27.9-fold) $(n=3)$, respectively. The abilities of various surface polysaccharides to inhibit or enhance the adherence of $A$. hydrophila PPD134/91 to EPC cells were also examined. Adhesion assay results showed that both purified $\mathrm{O}$-antigen and capsular polysaccharides failed to affect the adherence of PPD134/91 cells to EPC cells. When 0.1 and $0.6 \mu \mathrm{g}$ of purified O-antigen polysaccharide/ml were added, the adherence percentages of PPD134/91 were 102.2\% $\pm 0.1 \%$ and $100.5 \% \pm 0.1 \%(n=3)$ relative to the untreated control, respectively. When purified capsular polysaccharide was added at 0.1 and $0.6 \mu \mathrm{g} / \mathrm{ml}$, the adherence percentages of PPD134/91 were $102.1 \% \pm 0.1 \%$ and $104.3 \% \pm 0.1 \%(n=3)$, respectively.

Surface polysaccharides aid in serum resistance. In nonimmune hosts, the primary defense against invasive pathogens is mediated largely through activation of the alternative complement pathway. This is advantageous to the invading organism, because it is able to survive, multiply, and establish an infection in the early phase of invasion. Many pathogenic bacteria possess virulence determinants such as the $\mathrm{O}$-antigen polysaccharide, capsular polysaccharide, and outer membrane proteins. It has been suggested that the polysaccharides protect the bacteria against complement action by binding to $\mathrm{C} 3 \mathrm{~b}$, which is the cleavage product of the third complement component. This component is of central importance in complement-mediated killing. The formation of $\mathrm{C} 3 \mathrm{~b}$ through the alternative pathway is vital to nonimmune hosts. However, in strains that are resistant to complement-mediated killing, the longest polysaccharide chains of the LPS cause C3b binding and prevent the formation of the complement membrane attack complex (MAC), thus precluding cell lysis $(2,19)$. On the other hand, certain capsular polysaccharides can overcome the complement system by having components that inactivate C3b (11), or the abundant capsule can simply impede the access of the complement components to activators buried in the cell surface (30) such that the MAC formation is again prevented. In the present study, when the avirulent $A$. hydrophila strain PPD35/85 was treated with purified O-antigen or capsular polysaccharide from the virulent $A$. hydrophila strain PPD134/91 prior to incubation with naïve tilapia serum, its survival ability was enhanced (Fig. 4). This shows that both the O-antigen and capsular polysaccharides contribute to serum resistance. However, the purified polysaccharides are not able to totally abolish the bactericidal activity of tilapia serum. This may be because the purified polysaccharides are not able to cover the entire cell surface of the avirulent bacterium, unlike the situation with the wild-type virulent strain PPD134/91, in which these polysaccharides coat the bacterial cell completely. Alternatively, purified polysaccharides may randomly absorb some of the complement proteins and decrease part of the complement-mediated bactericidal activity. These results suggested that the O-antigen and capsular polysaccharides of strain PPD134/91 might serve as a double barrier to block complement-mediated bactericidal activity. On a weight basis, we do not know why the capsule is significantly more effective than the O-antigen polysaccharide in protecting $A$. hydrophila PPD35/85 against serum-mediated killing (Fig. 4). The O-antigen LPS of $A$. hydrophila O:34 strains has been found to play an important role in adhesion to HEp-2 cells (31). However, we could not observe a similar inhibitory effect on the adhesion of $A$. hydrophila PPD134/91 (O:18) to EPC cells. This may be an indication that different serogroups use different mechanisms for adhesion and invasion.

In conclusion, we have presented in this paper the sequences and genetic organization of $A$. hydrophila PPD134/91 surface polysaccharide gene clusters. We have shown that this strain may belong to the O:18 serogroup and that the capsule organization is similar to that of the group II capsule of other bacteria. We have also demonstrated that both $\mathrm{O}$-antigen and capsular polysaccharides of PPD134/91 are capable of conferring resistance to serum-mediated killing on the avirulent strain. Although there are several genes in both gene clusters for which functions cannot be deduced, our study should facilitate understanding of the genetics of the surface polysaccharides of Aeromonas and their roles in pathogenesis.

\section{ACKNOWLEDGMENTS}

We are grateful to the National University of Singapore for providing a research grant for this work.

We thank Peter Howard and Shashikant Joshi for constructive criticism.

\section{REFERENCES}

1. Aguilar, A., S. Merino, M. M. Nogueras, M. Regue, and J. M. Tomas. 1999. Two genes from the capsule of Aeromonas hydrophila (serogroup O:34) confer serum resistance to Escherichia coli K12 strains. Res. Microbiol. 150:395-402.

2. Alberti, S., D. Alvarez, S. Merino, M. T. Casado, F. Vivanco, J. M. Tomas, and V. J. Benedi. 1996. Analysis of complement C3 deposition and degradation on Klebsiella pneumoniae. Infect. Immun. 64:4726-4732.

3. Aoyama, K., A. M. Haase, and P. R. Reeves. 1994. Evidence for effect of random genetic drift on $\mathrm{G}+\mathrm{C}$ content after lateral transfer of fucose pathway genes to Escherichia coli K-12. Mol. Biol. Evol. 11:829-838.

4. Austin, B., and C. Adams. 1996. Fish pathogens, p. 197-243. In B. Austin, M. Altwegg, P. J. Gosling, and S. W. Joseph (ed.), The genus Aeromonas. John Wiley and Sons, New York, N.Y.

5. Bhasin, N., A. Albus, F. Michon, P. J. Livolsi, J. S. Park, and J. C. Lee. 1998. Identification of a gene essential for O-acetylation of the Staphylococcus aureus type 5 capsular polysaccharide. Mol. Microbiol. 27:9-21.

6. Boyce, J. D., J. Y. Chung, and B. Adler. 2000. Genetic organization of the capsule biosynthetic locus of Pasteurella multocida M1404 (B:2). Vet. Microbiol. 72:121-134.

7. Bugert, P., and K. Geider. 1995. Molecular analysis of the ams operon required for exopolysaccharide synthesis of Erwinia amylovora. Mol. Microbiol. 15:917-933.

8. Chung, J. Y., Y. Zhang, and B. Alder. 1998. The capsule biosynthetic locus of Pasteurella multocida A:1. FEMS Microbiol. Lett. 166:289-296.

9. Clarke, B. R., R. Pearce, and I. S. Roberts. 1999. Genetic organization of the Escherichia coli $\mathrm{K} 10$ capsule gene cluster: identification and characterization of two conserved regions in group III capsule gene clusters encoding polysaccharide transport functions. J. Bacteriol. 181:2279-2285.

10. Comstock, L. E., M. J. Coyne, A. O. Tzianabos, A. Pantosti, A. B. Onderdonk, and D. L. Kasper. 1999. Analysis of a capsular polysaccharide biosynthesis locus of Bacteroides fragilis. Infect. Immun. 67:3525-3532.

11. Fearon, D. T. 1978. Regulation by membrane sialic acid of $\beta 1 \mathrm{H}$-dependent decay-dissociation of amplification C3 convertase of the alternative complement pathway. Proc. Natl. Acad. Sci. USA 75:1971-1975.

12. Frosch, M., and A. Muller. 1993. Phospholipid substitution of capsular polysaccharides and mechanisms of capsule formation in Neisseria meningitidis. Mol. Microbiol. 8:483-493.

13. Frosch, M., C. Weisgerber, and T. F. Meyer. 1989. Molecular characterization and expression in Escherichia coli of the gene complex encoding the polysaccharide capsule of Neisseria meningitidis group B. Proc. Natl. Acad. Sci. USA 86:1669-1673.

14. Glaser, P., F. Kunst, M. Arnaud, M. P. Coudart, W. Gonzales, M. F. Hullo, M. Ionescu, B. Lubochinsky, L. Marcelino, I. Moszer, E. Presecan, M. Santana, E. Schneider, J. Schweizer, A. Vertes, G. Rapoport, and A. Danchin. 1993. Bacillus subtilis genome project: cloning and sequencing of the $97 \mathrm{~kb}$ region from 325 degrees to 333 degrees. Mol. Microbiol. 10:371384.

15. Heidelberg, J. F., J. A. Eisen, W. C. Nelson, R. A. Clayton, M. L. Gwinn, R. J. Dodson, D. H. Haft, E. K. Hickey, J. D. Peterson, L. A. Umayam, S. R. Gill, K. E. Nelson, T. D. Read, H. Tettelin, D. Richardson, M. D. Ermolaeva, J. 
Vamathevan, S. Bass, H. Qin, I. Dragoi, P. Sellers, L. McDonald, T. Utterback, R. D. Fleishmann, W. C. Nierman, O. White, S. L. Salzberg, H. O. Smith, R. R. Colwell, J. J. Mekalanos, J. C. Venter, and C. M. Fraser. 2000. DNA sequence of both chromosomes of the cholera pathogen Vibrio cholerae. Nature 406:477-483.

16. Hobbs, M., and P. R. Reeves. 1994. The JUMPstart sequence: a 39-bp element common to several polysaccharide gene clusters. Mol. Microbiol. 12:855-856.

17. Janda, J. M., L. S. Guthertz, R. P. Kokka, and T. Shimada. 1994. Aeromonas species in septicemia: laboratory characteristics and clinical observations. Clin. Infect. Dis. 19:77-83.

18. Jiang, X. M., B. Neal, F. Santiago, S. J. Lee, L. K. Romana, and P. R. Reeves. 1991. Structure and sequence of the $r f b$ (O antigen) gene cluster of Salmonella serovar Typhimurium (strain LT2). Mol. Microbiol. 5:695-713.

19. Joiner, K. A., N. Grossman, M. Schmetz, and L. Leive. 1986. C3 binds preferentially to long-chain lipopolysaccharide during alternative pathway activation by Salmonella montevideo. J. Immunol. 136:710-715.

20. Joiner, K. A. 1988. Complement evasion by bacteria and parasites. Annu. Rev. Microbiol. 42:201-230.

21. Kokka, R. P., and J. M. Janda. 1990. Isolation and identification of autoagglutinating serogroup O:11 Aeromonas strains in the clinical laboratory. J. Clin. Microbiol. 28:1297-1299.

22. Kuhn, H. M., U. Meier, and H. Mayer. 1984. ECA, das gemeinsame Antigen der Enterobacteriaceae-Stiefkind der Mikrobiologie. Forum Microbiol. 7:274-285

23. Lee, S. J., L. K. Romana, and P. R. Reeves. 1992. Sequence and structural analysis of the $r f b$ (O antigen) gene cluster from a group C1 Salmonella enterica strain. J. Gen. Microbiol. 138:1843-1855.

24. Li, Q., and P. R. Reeves. 2000. Genetic variation of dTDP-L-rhamnose pathway genes in Salmonella enterica. Microbiology 146:2291-2307.

25. Lin, C. S., and S. H. Cheng. 1998. Aeromonas hydrophila sepsis presenting as meningitis and necrotizing fasciitis in a man with alcoholic liver cirrhosis. J. Formos. Med. Assoc. 97:498-502.

25a.Lo, R. Y. C., L. J. McKerral, T. L. Hills, and M. Kostrzynska. 2001. Analysis of the capsule biosynthetic locus of Mannheimia (Pasteurella) haemolytica A1 and proposal of a nomenclature system. Infect. Immun. 69:4458-4464.

26. Makino, K., K. Yokoyama, Y. Kubota, C. H. Yutsudo, S. Kimura, K. Kurokawa, K. Ishii, M. Hattori, I. Tatsuno, H. Abe, T. Iida, K. Yamamoto, M. Ohnishi, T. Hayashi, T. Yasunaga, T. Honda, C. Sasakawa, and H. Shinagawa. 1999. Complete nucleotide sequence of the prophage VT2-Sakai carrying the verotoxin 2 genes of the enterohemorrhagic Escherichia coli O157:H7 derived from the Sakai outbreak. Genes Genet. Syst. 74:227-239.

27. Marolda, C. L., and M. A. Valvano. 1995. Genetic analysis of the dTDPrhamnose biosynthesis region of the Escherichia coli VW187 (O7:K1) rfb gene cluster: identification of functional homologs of $r f b B$ and $r f b A$ in the $r f f$ cluster and correct location of the rffE gene. J. Bacteriol. 177:5539-5546.

28. Martin, M. C., D. Schneider, C. J. Bruton, K. F. Chater, and C. Hardisson. 1997. A $g l g C$ gene essential only for the first of two spatially distinct phases of glycogen synthesis in Streptomyces coelicolor A3(2). J. Bacteriol. 179:77847789 .

29. Martinez, M. J., D. S. Pujol, F. Congrefado, S. Merino, X. Rubires, and J. M. Tomas. 1995. The presence of capsular polysaccharide in mesophilic Aeromonas hydrophila serotypes O:11 and O:34. FEMS Microbiol. Lett. 128:6974.

30. Merino, S., S. Camprubi, S. Alberti, V. J. Benedi, and J. M. Tomas. 1992. Mechanisms of Klebsiella pneumoniae resistance to complement-mediated killing. Infect. Immun. 60:2529-2535.

31. Merino, S., X. Rubires, A. Aguilar, and J. M. Tomas. 1996. The O:34-antigen lipopolysaccharide as an adhesin in Aeromonas hydrophila. FEMS Microbiol. Lett. 139:97-101.

32. Miyake, M., K. Iga, C. Izumi, A. Miyagawa, Y. Kobashi, and T. Konishi. 2000. Rapidly progressive pneumonia due to Aeromonas hydrophila shortly after near-drowning. Intern. Med. 39:1128-1130.

33. Morona, J. K., R. Morona, and J. C. Paton. 1997. Molecular and genetic characterization of the capsule biosynthesis locus of Streptococcus pneumoniae type 19B. J. Bacteriol. 179:4953-4958.

34. Moses, A. E., M. Leibergal, G. Rahav, M. Perouansky, R. Or, and M. Shapiro. 1995. Aeromonas hydrophila myonecrosis accompanying mucormycosis five years after bone marrow transplantation. Eur. J. Clin. Microbiol. Infect. Dis. 14:237-240.

35. Munoz, P., V. Fernandez-Baca, T. Pelaez, R. Sanchez, M. Rodriguez-Creixems, and E. Bouza. 1994. Aeromonas peritonitis. Clin. Infect. Dis. 18:32-37.

36. Mustaftschiev, S., J. Vasse, and G. Truchet. 1982. Exostructures of Rhizobium meliloti. FEMS Microbiol. Lett. 13:171-175.

37. Nishijyo, T., S. M. Park, C. D. Lu, Y. Itoh, and A. T. Abdelal. 1998. Molecular characterization and regulation of an operon encoding a system for transport of arginine and ornithine and the ArgR regulatory protein in Pseudomonas aeruginosa. J. Bacteriol. 180:5559-5566.

38. Ophir, T., and D. L. Gutnick. 1994. A role for exopolysaccharides in the protection of microorganisms from desiccation. Appl. Environ. Microbiol. 60:740-745.
39. Orskov, I., and F. Orskov. 1984. Serotyping of Klebsiella. Methods Microbiol. 14:143-164.

40. Parkhill, J., B. W. Wren, K. Mungall, J. M. Ketley, C., Churcher, D. Basham, T. Chillingworth, R. M. Davies, T. Feltwell, S. Holroyd, K. Jagels, A. Karleyshev, S. Moule, M. J. Pallen, C. W. Penn, M. Quail, M. A. Rajandream, K. M. Rutherford, A. Vanvliet, S. Whitehead, and B. G. Barrell. 2000. The genome sequence of the food-borne pathogen Campylobacter jejuni reveals hypervariable sequences. Nature 403:665-668.

40a.Parkhill, J., G. Dougan, K. D. James, N. R. Thomson, D. Pickard, J. Wain, C. Churcher, K. L. Mungall, S. D. Bentley, M. T. G. Holden, M. Sebaihia, S. Baker, D. Basham, K. Brooks, T. Chillingworth, P. Connerton, A. Cronin, P. Davis, R. M. Davis, L. Dowd, N. White, J. Farrar, T. Feltwell, N. Hamlin, A Haque, T. T. Hien, S. Holroyd, K. Jagels, A. Krogh, T. S. Larsen, S. Leather, S. Moule, P. O'Gaora, C. Parry, M. Quail, K. Rutherford, M. Simmonds, J. Skelton, K. Stevens, S. Whitehead, and B. G. Barrell. 2001. Complete genome sequence of a multiple drug resistant Salmonella enterica serovar typhi CT18. Nature 413:848-852.

41. Pavelka, M. S., Jr., L. F. Wright, and R. P. Silver. 1991. Identification of two genes, $k p s M$ and $k p s T$, in region 3 of the polysialic acid gene cluster of Escherichia coli K1. J. Bacteriol. 173:4603-4610.

42. Pazzani, C., C. Rosenow, G. J. Boulnois, D. Bronner, K. Jann, and I. S Roberts. 1993. Molecular analysis of region 1 of the Escherichia coli K5 antigen gene cluster: a region encoding proteins involved in cell surface expression of capsular polysaccharide. J. Bacteriol. 175:5978-5983.

43. Poole, K., K. Krebes, C. McNally, and S. Neshat. 1993. Multiple antibiotic resistance in Pseudomonas aeruginosa: evidence for involvement of an efflux operon. J. Bacteriol. 175:7363-7372.

44. Reeves, P. R., M. Hobbs, M. A. Valvano, M. Skurnik, C. Whitfield, D. Coplin, N. Kido, J. Klena, D. Maskell, C. R. H. Raetz, and P. D. Rick. 1996. Bacterial polysaccharide synthesis and gene nomenclature. Trends Microbiol. 4:495503

45. Rigg, G. P., B. Barrett, and I. S. Roberts. 1998. The localization of KpsC, S and $\mathrm{T}$ and KfiA, C and $\mathrm{D}$ proteins involved in the biosynthesis of the Escherichia coli K5 capsular polysaccharide: evidence for a membrane-bound complex. Microbiology 144:2905-2914.

46. Roberts, I. S. 1996. The biochemistry and genetics of capsular polysaccharide production in bacteria. Annu. Rev. Microbiol. 50:285-315.

47. Rubens, C. E., L. M. Heggen, R. F. Haft, and M. R. Wessels. 1993. Identification of $c p s D$, a gene essential for type III capsule expression in group B streptococci. Mol. Microbiol. 8:843-855.

48. Russo, T. A., S. Wenderoth, U. B. Carlino, J. M. Merrick, and A. J. Lesse. 1998. Identification, genomic organization, and analysis of the group III capsular polysaccharide genes $k p s D, k p s M$, kpsT, and $k p s E$ from an extraintestinal isolate of Escherichia coli (CP9, O4/K54/H5). J. Bacteriol. 180:338349

49. Saigi, F., N. Climent, N. Pique, C. Sanchez, S. Merino, X. Rubires, A. Aguilar, J. M. Tomas, and M. Regue. 1999. Genetic analysis of the Serratia marcescens N28b O4 antigen gene cluster. J. Bacteriol. 181:1883-1891.

50. Sakazaki, R., and T. Shimada. 1984. O-serogrouping scheme for mesophilic Aeromonas strains. Jpn. J. Med. Sci. Biol. 37:247-255.

51. Sambrook, J., E. F. Fritsch, and T. Maniatis. 1989. Molecular cloning: a laboratory manual, 2nd ed. Cold Spring Harbor Laboratory Press, Cold Spring Harbor, N.Y.

52. Schnaitman, C. A., and J. D. Klena. 1993. Genetics of lipopolysaccharide biosynthesis in enteric bacteria. Microbiol. Rev. 57:655-682.

53. Shaw, D. H., and M. J. Squire. 1984. O-antigen structure in a virulent strain of Aeromonas hydrophila. FEMS Microbiol. Lett. 24:277-280.

54. Skurnik, M., A. Peippo, and E. Ervela. 2000. Characterization of the Oantigen gene clusters of Yersinia pseudotuberculosis and the cryptic O-antigen gene cluster of Yersinia pestis shows that the plague bacillus is most closely related to and has evolved from $Y$. pseudotuberculosis serotype O:1b. Mol. Microbiol. 37:316-330.

55. Smith, A. N., G. J. Boulnois, and I. S. Roberts. 1990. Molecular analysis of the Escherichia coli $\mathrm{K} 5 \mathrm{kps}$ locus: identification and characterization of an inner-membrane capsular polysaccharide transport system. Mol. Microbiol. 4:1863-1869.

56. Smith, H. E., M. Damman, J. van der Velde, F. Wagenaar, H. J. Wisselink, N. Stockhofe-Zurwieden, and M. A. Smits. 1999. Identification and characterization of the cps locus of Streptococcus suis serotype 2: the capsule protects against phagocytosis and is an important virulence factor. Infect. Immun. 67:1750-1756.

57. Stevenson, G., A. Kessler, and P. R. Reeves. 1995. A plasmid-borne Oantigen chain length determinant and its relationship to other chain length determinants. FEMS Microbiol. Lett. 125:23-30.

58. Stevenson, G., K. Andrianopoulos, M. Hobbs, and P. R. Reeves. 1996. Organization of the Escherichia coli $\mathrm{K}-12$ gene cluster responsible for production of the extracellular polysaccharide colanic acid. J. Bacteriol. 178:48854893.

59. Swartley, J. S., L. J. Liu, Y. K. Miller, L. E. Martin, S. Edupuganti, and D. S. Stephens. 1998. Characterization of the gene cassette required for biosynthesis of the $(\alpha 1 \rightarrow 6)$-linked $N$-acetyl-D-mannosamine-1-phosphate capsule of serogroup A Neisseria meningitidis. J. Bacteriol. 180:1533-1539. 
60. Thomas, L. V., R. J. Gross, T. Cheasty, and B. Rowe. 1990. Extended serogrouping scheme for motile, mesophilic Aeromonas species. J. Clin. Microbiol. 28:980-984.

61. Townsend, K. M., J. D. Boyce, J. Y. Chung, A. J. Frost, and B. Adler. 2001 Genetic organization of Pasteurella multocida cap loci and development of a multiplex capsular PCR typing system. J. Clin. Microbiol. 39:924-929.

62. Wang, L., H. Curd, W. Qu, and P. R. Reeves. 1998. Sequencing of Escherichia coli $\mathrm{O} 111 \mathrm{O}$-antigen gene cluster and identification of O111-specific genes. J. Clin. Microbiol. 36:3182-3187.

63. Wang, L., S. Jensen, R. Hallman, and P. R. Reeves. 1998. Expression of the $\mathrm{O}$ antigen cluster is regulated by $\mathrm{RfaH}$ through the JUMPstart sequences. FEMS Microbiol. Lett. 165:201-206.

64. Wang, X. H., H. L. Ong, G. W. P. Ho, W. S. F. Wang, T. M. Lim, and K. Y. Leung. 1998. Internalization and cytotoxicity are important virulence mechanisms in vibrio-fish epithelial cell interaction. Microbiology 144: 2987-3002.

65. Westphal, O., and K. Jann. 1965. Bacterial lipopolysaccharides. Methods Carbohydr. Chem. 5:83-91.
66. Whitfield, C. 1995. Biosynthesis of lipopolysaccharide O antigen. Trends Microbiol. 3:178-185.

67. Whitfield, C., and I. S. Roberts. 1999. Structure, assembly and regulation of expression of capsule in Escherichia coli. Mol. Microbiol. 31:1307-1319.

68. Wunder, D. E., W. Aaronson, S. F. Hayes, J. M. Bliss, and R. P. Silver. 1994 Nucleotide sequence and mutational analysis of the gene encoding KpsD, a periplasmic protein involved in transport of polysialic acid in Escherichia coli K1. J. Bacteriol. 176:4025-4033.

69. Yao, Z., and M. A. Valvano. 1994. Genetic analysis of the O-specific lipopolysaccharide biosynthesis region $(r f b)$ of Escherichia coli K-12 W3110: identification of genes that confer group 6 specificity to Shigella flexneri serotypes Y and 4a. J. Bacteriol. 176:4133-4143.

70. Yoshida, Y., Y. Nakano, Y. Yamashita, and T. Koga. 1998. Identification of a genetic locus essential for serotype b-specific antigen synthesis in Actinobacillus actinomycetemcomitans. Infect. Immun. 66:107-114.

71. Zhang, Y. L., C. T. Ong, and K. Y. Leung. 2000. Molecular analysis of genetic differences between virulent and avirulent strains of Aeromonas hydrophila isolated from diseased fish. Microbiology 146:999-1009.

Editor: R. N. Moore 